\title{
The Influence of the Discipline of Online Assignment Collection Assisted by Edlink Sevima on the Learning Outcomes
}

\author{
Meidawati Suswandari ${ }^{*}$ \\ ${ }^{1}$ Primary School Teacher Education, Universitas Veteran Bangun Nusantara, Indonesia
}

\section{A R T I C L E I N F O}

Article history:

Received September 10, 202

Revised September 11, 2021

Accepted October 11, 2021

Available online November 25, 2021

Kata Kunci:

Disiplin Tugas Daring, Edlink Sevima, Hasil Belajar

Keywords:

Online Assignment Discipline,

Edlink Sevima, Learning outcomes

DOI:

https://dx.doi.org/10.23887/jet.v5i4. 41015

\begin{abstract}
A B S T RA K
Interaksi mahasiswa dan dosen sangat penting dalam pembelajaran. Tidak ada tatap muka di kelas secara intensif selama pandemi Covid-19 berimbas pada sikap disiplin mahasiswa dalam penugasan. Hal ini berdampak pada rendahnya hasil belajar mahasiswa. Tujuan penelitian ini yaitu untuk menganalisis disiplin pengumpulan tugas daring berbantuan Edlink sevima terhadap hasil belajar mahasiswa. Penelitian ini menggunakan penelitian kuantitatif. Metode penelitian ini yaitu kuantitatif. Sampel penelitian adalah 42 siswa. Teknik pengumpulan data dengan dua cara, yaitu dengan angket dan tes. Instrument yang digunakan dalam mengumpulkan data yaitu kuesioner. Uji instrumen penelitian meliputi uji validitas dan uji reliabilitas. Analisis data menggunakan uji statistic. Hasil penelitian menunjukan bahwa rhitung sebesar 0,656, dan dikonsultasikan dengan $r_{\text {tabel }}$ Product Moment tarafsignifikan 5\% dengan $N=22$ adalah 0,423. Sehingga dapat dinyatakan $r_{\text {hitung }} 0,656>r_{\text {tabel }} 0,423$ dan mengandung arti hipotesis yang diajukan dapat diterima. Implikasi penelitian ini dalam pembelajaran disiplin pengumpulan tugas daring penting diterapkan saat belajar, mahasiswa yang memiliki sikap disiplin belajar yang tinggi hasil belajar yang diperoleh mahasiswa juga tinggi yaitu hasil belajar. Hal ini terlihat dari hasil penelitian yang menyatakan ada Pengaruh disiplin pengumpulan tugas daring berbantuan Edlink Sevima terhadap hasil belajar.
\end{abstract}

\section{A B S T R A C T}

The interaction of students and lecturers is essential in learning. There is no face-to-face in class intensively the Covid-19 pandemic has an impact on student discipline in assignments. It has an impact on the low student learning outcomes. This study aims to analyze the collection of bold assignments assisted by Edlink Sevima on student learning outcomes. This research uses quantitative research. This research method is quantitative. The research sample was 42 students-data collection techniques were used in two ways: questionnaires and tests. The instrument used in collecting data is a questionnaire. Research test instruments include validity and reliability tests. Data analysis using statistical tests. The results showed that the rcount was 0.656, and in consultation with the Product Moment rtable, the significance level of 5\% with $\mathrm{N}=$ 22 was 0.423 . So it can be stated that rcount $0.656>$ rtable 0.423 implies that the proposed hypothesis can be accepted. The implication of this research in learning is that it is essential to apply courageous task collection when studying. For students who have a high learning discipline attitude, the learning outcomes obtained are also high, namely learning outcomes. The results of the research state that there is an effect of collecting daring tasks assisted by Edlink Sevima on learning outcomes.

This is an open access article under the CC BY-SA license. Copyright (C) 2021 by Author. Published by Universitas Pendidikan Ganesha.

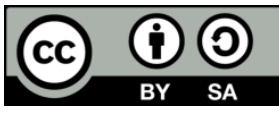

\section{INTRODUCTION}

At this time information and communication technology is an inseparable part of various aspects of human life, including the implementation of education (Bastemur \& Bastemur, 2015; Blakely et al., 2020; Mulyani, 2013). In schools, ICT is used starting from simple things to make reports, prepare budgets, manage student data, grades to use in the learning process (Aini et al., 2020; Mutohhari et al., 2021). The application of ICT in schools requires education actors to be technology literate, the impact of which is that every educator and education staff must be able to use computers (Eugenia et al., 2013; Kim et al., 2020; Purwowidodo, 2017). All learning models in schools must begin to move from conventional systems to systems that lead to ICT, including learning applications (Lange et al., 2020; Rajagukguk \& Simanjuntak, 2015). The use of e-learning in learning activities in schools and universities, along with the development of information technology and the demands of globalization of education and distance learning, various concepts have been developed to replace traditional learning methods (Anitha Kumari et al., 2020; Khan et al., 2021; Kyewski \& Krämer, 2018). In the current 
pandemic situation, learning is more effective using digital learning, because the direct teaching and learning process is still not held considering the Covid-19 in the world of education in Indonesia is replaced by online learning (Anitha Kumari et al., 2020; Hoi et al., 2021; Wijaya et al., 2021).

During the pandemic period, our attention was seized when students had to do lecturer assignments, the interaction between students and lecturers was not optimal, and students' affective assessment was not optimal due to the absence of intensive face-to-face meetings in class (Arizona et al., 2020; Hutauruk \& Sidabutar, 2020). Government policies during the Covid-19 pandemic through studying at home have an impact on student discipline in assignments (Shodiq \& Zainiyati, 2020; Windhiyana, 2020). It appears in certain cases, students are bored because they are always given assignments by the lecturer (Abidah et al., 2020; Meriana et al., 2021; Putri et al., 2021; Sari et al., 2021). However, lecturers must always innovate learning to be more interesting, not boring and creative. The reciprocal relationship between lecturers and students will affect the acquisition of complete learning during online learning. Likewise with student discipline, especially in the accuracy of online assignment collection, which the lecturer informs through the Google Classroom, Edmodo, Edlink Sevima, and Spada applications (Putra, 2021; Wan Hassan et al., 2020). A case was found in the fourth semester students of the PGSD Univet Bantara study program who lacked discipline during online assignments from the eldink sevima application. This can be seen from some students doing private WhatsApp to the lecturer to ask for more time to do assignments. In addition, there are students because they are working while studying online. There are also students who often rely on assignments by waiting for an answer from their friends so that when uploading the assignment file, the time is tight.

EdLink Sevima as an online learning supporter that adapts to the needs of the digitalization era to produce the skills of teachers and students as skilled and skilled workers who are able to adapt to the demands and needs of IT-based learning by considering values including economic value, functional value, psychological values and creative values and innovative values (Wibowo \& Rahmayanti, 2020). Learning discipline is very necessary in forming a learning attitude according to the norm (Alavudeen et al., 2021; Thoyyibah et al., 2019). One of the things that affect the success of learning is the student's learning discipline, starting from the time, how to learn, readiness in learning, and the rules in learning. With high learning discipline, the learning outcomes obtained will be high and vice versa, if the learning discipline is low, the learning outcomes obtained will also not be optimal (Arico et al., 2018; Lyashenko \& Malinina, 2015). The use of the Sevima EdLink application to support online learning during this pandemic (Wibowo \& Rahmayanti, 2020). The teachers are very enthusiastic in participating in counseling related to understanding the services available at Sevima EdLink, especially when making classes and providing teaching materials in the form of ppt files, lin and also learning videos, making it easier for students to receive the materials via laptops or laptops. smartphone without having to install. Efforts to spur student learning discipline through the use of learning applications with the Edlink Sevima platform. Edlink Sevima is successful in helping students learn by providing materials in the form of practice questions and discussions to prepare for remedial exams (Marlina, 2020; Wibowo \& Rahmayanti, 2020). Indirectly, the provision of materials and practice questions on the Sevima Edlink application encourages students to read return the material given in lectures in order to prepare for the remedial exam. The contribution of this research is the significance of a learning process in a pandemic mass, because during the pandemic, many things are considered to provide leeway for students without face to face, but some aspects of assignments that they always get from each lecturer assignment or course at each session/meeting online. This can also be understood by the lecturer in charge of the course when giving student assignments, there are certain factors that cause maximum student learning completeness when studying online. Likewise, the use of the Edlink Sevima application, as a learning platform to anticipate students only asking for assignments via email or WhatsApp Group. Therefore, this study aims to determine the effect of the discipline of collecting online assignments assisted by Edlink Sevima on the learning outcomes of PGSD Univet Bantara students.

\section{METHOD}

This research uses quantitative research. Quantitative research is a process of finding knowledge that uses data in the form of numbers as a tool to find information about what we want to know. In this study there are two variables, namely: The independent variable (independent variable). In this study, the independent variable is the discipline of collecting online assignments assisted by Edlink Sevima, which is symbolized by (X). The dependent variable (dependent variable). In this study the dependent variable is student learning outcomes which are denoted by (Y). In this study, the population was 86 students from PGSD Univet Bantara in the fourth semester. The research sample is 42 students. This study uses data collection techniques in two ways, namely by questionnaires and tests. Questionnaires for class IV A students totaled 22 students. The questionnaire consists of several statements where students just choose one of the 4 options that have been prepared. Measurements with 4 scales and items consist of positive and negative. The scores for positive items are always $=4$, often $=3$, sometimes $=2$, and never $=1$, and vice versa. The instrument in this study uses a measuring 
instrument with a modification of the Likert scale. The Likert scale is used to measure attitudes, opinions and perceptions of a person or group about social events or phenomena. Measurements with a Likert scale have a gradation from positive to negative. The test is a series of questions or practice questions and other tools used to measure the skills, knowledge, intelligence, and abilities that individuals have. This study uses an intelligence test in the form of multiple choice to measure the learning outcomes of fourth semester students of PGSD Univet Bantara.

Instruments related to student learning discipline variables in online assignment collection assisted by Edlink Sevima were tested on non-respondents, namely class IV C students with a total of 20 students who have characteristics that are close to the characteristics of the research subjects in this study. The formula used to test the validity of the questionnaire items is the Product Moment correlation formula proposed by Pearson with the formula (Arikunto, 2010). The technique used to test the reliability of the questionnaire is the halving technique (odd and even halves) using the Product Moment formula. This study analyzed the data using statistics. Statistics are scientific methods that are prepared to collect, submit, and analyze data in the form of numbers. This study is to determine the relationship between two variables using the product moment correlation formula /rough number formula. The formula is to test whether there is a relationship between the discipline of collecting online assignments assisted by Edlink Sevima on student learning outcomes..

\section{RESULT AND DISCUSSION}

\section{Result}

This study was aimed at students of PGSD Univet Bantara by first testing the research instrument in class IV C. Testing on the instrument in the study was conducted to determine the validity and reliability of the instrument to be used. The instrument trial in this study was carried out on the discipline questionnaire items for collecting online assignments assisted by Edlink Sevima on student learning outcomes. The Edlink Sevima application is applied in learning during distance learning with the following activity display.

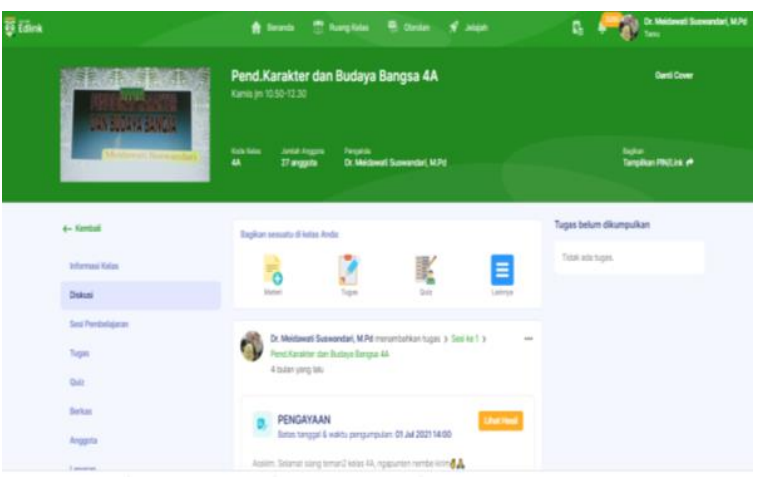

Figure 1. Display of Class IVA in informing Materials and Assignments

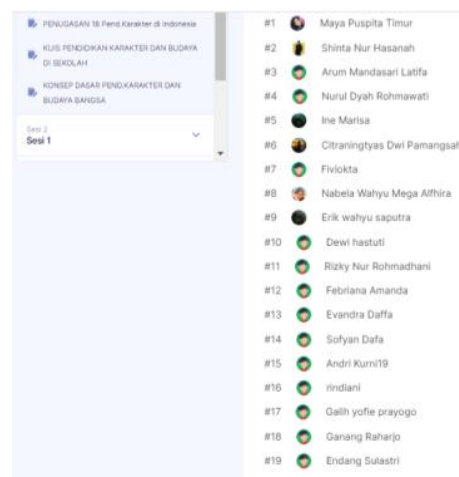

Figure 2. Display of Class IVA in Evaluation of Learning Outcomes

Test the validity of the discipline questionnaire items for online assignment collection assisted by Edlink Sevima. The questionnaire was tested on 20 students with a total of 40 question items. Tests were carried out on the questionnaire items using the Product Moment correlation formula. The calculation results obtained that the correlation coefficient of item number 1 is 0.3302 . While the $r$ table with $\mathrm{N}=20$ significant $5 \%$ is 0.444 because $\mathrm{r}$ count $<\mathrm{r}$ table ie $0.3302<0.444$, the correlation coefficient indicates that item number 1 is proven invalid. After looking at the validity calculation table, from 40 question items, the discipline questionnaire for online assignment collection assisted by Edlink Sevima which was tested on 20 respondents, consulted with rtable $=0.444$ it can be seen that 30 items are valid, and 10 are invalid, thus 30 question items can be used to collect data in this study. The calculation results obtained that the correlation coefficient of item number 2 is 0.689 . While the $\mathrm{r}$ table with $\mathrm{N}=20$ significant $5 \%$ is 0.444 because $r$ count $>r$ table that is $0.689>0.444$, the correlation coefficient indicates that item number 2 is proven valid. To find the reliability of the questionnaire in this study, the data split technique was sought (Spearmen Brown), namely by splitting the odd numbered item $(\mathrm{X})$ and the even numbered test item (Y). The results of the rtable price of 0.444 with $\mathrm{N}=20$ and a significance level of $5 \%$. From the data above, it is found that rcount is greater than rtable $(0.8485>0.444)$ which means that there is a significant correlation and the instrument is reliable. Test the reliability of student learning outcomes To find the reliability of the questionnaire in this study, the data split technique was sought (Spearmen Brown), namely by splitting the odd numbered item (X) and the even numbered test item (Y). Finding the reliability of student learning outcomes of PGSD Univet Bantara was obtained with a rtable price of 0.444 with $\mathrm{N}=20$ and a 
significance level of 5\%. From the data above, it is found that rcount is greater than rtable $(0.8668>0.444)$ which means that there is a significant correlation and the instrument is reliable.

\section{Discussion}

From the results of the questionnaire, it was proven that some students had quite high discipline in collecting online assignments assisted by Edlink Sevima but some were lacking. Not all students apply a disciplined attitude in their studies. on the learning outcomes obtained by all students, the results obtained are quite good but there are still many who still have not reached the KKM value that has been applied in the school, which is less than 75. Discipline is something that is integrated within oneself. somebody. Even discipline becomes a part of a person's life, which appears in his daily behavior (Suyanto, 2018; Yuliandi \& Tahir, 2019). Discipline occurs and is formed as a result and impact of a fairly long coaching process carried out from within the family and continues in education at school, because basically the family and school become an important place for the development of one's discipline (Herman \& Didin, 2020; Hidayati et al., 2019). Furthermore Previous research added the function of discipline (Hu \& Liu, 2020; Marzuki \& Basariah, 2017). Organizing life together. Humans are social creatures. Humans will not be able to live without the help of others. In social life, there are often conflicts between people caused by conflict of interest, because humans are not only social beings (Daunic et al., 2021; Hofmann \& Müller, 2021). Build a good personality. Personality is the overall characteristic, characteristic behavior possessed by a person (Vollmer et al., 2014; Yu, 2021). Between one person with another person has a different personality. An environment with good discipline greatly influences a person's personality. Training a good personality is built from an early age, it also needs to be trained because good discipline does not appear by itself (Hazrati-Viari et al., 2012; Nießen et al., 2020). A good personality needs to be trained and accustomed, attitudes, behavior and patterns of life and discipline are not formed in a short time, but through a process that takes a long time (Ko et al., 2010).

Discipline will be created with a person's awareness to comply with all applicable provisions, regulations, and norms in carrying out duties and responsibilities (Baehaqi, 2020; Wegmann \& Smith, 2019). Discipline with self-awareness motives is better and stronger (Purvis et al., 2020; Wagiran et al., 2019). Punishment. Punishment plays a very important role because it can provide motivation and strength for students to comply with existing rules and regulations, because without punishment it is very doubtful that students obey the rules that have been determined. Creating a conducive environment. Discipline in schools serves to support the implementation of the process of educational activities running smoothly (Pratama et al., 2021; Toropova et al., 2021; Wegmann \& Smith, 2019). This is achieved by drafting school regulations, namely regulations for lecturers and for students, as well as other regulations deemed necessary. The implication of this research in learning that it is important to apply bold assignments when studying, students who have a high learning discipline attitude, the learning outcomes obtained are also high, namely learning outcomes. In addition, in the long term, lecturers can also explain and apply the discipline of collecting assignments that are bravely assisted by Edlink Sevima to students in order to obtain optimal results. Lecturers provide guidance and motivation related to the discipline of collecting assignments from the assistance of Edlink Sevima on the learning outcomes of PGSD Univet Bantara students as expected. Students must obey and carry out the orders given by the lecturer, and apply attitudes in learning in order to obtain the results given. The contribution of this research can be a reference for lecturers or other teachers in utilizing bold learning using delink sevima. It is also hoped that future researchers can conduct similar research with different types of research and research designs. In addition, it can innovate this sevima delink in the form of bold learning which is even more interesting.

\section{CONCLUSION}

The results of the study stated that there was an effect of collecting daring assignments with the help of Edlink Sevima on the learning outcomes of PGSD Univet Bantara students. Edlink Sevima was able to innovate learning, especially in the brave assignments of students during the covid-19 pandemic. Especially with a disciplined attitude in collecting online assignments, it is important to apply when studying. Students who have a high learning discipline attitude, the learning outcomes obtained are also high, namely learning outcomes.

\section{REFERENCES}

Abidah, A., Hidaayatullaah, H. N., Simamora, R. M., Fehabutar, D., \& Mutakinati, L. (2020). The Impact of COVID-19 to Indonesian Education and Its Relation to the Philosophy of "Merdeka Belajar." Studies in $\begin{array}{lllll}\text { Philosophy of } & \text { Science } & \text { Education, } & \text { 1(1), }\end{array}$ https://doi.org/https://doi.org/10.46627/sipose.v1i1.9. 
Aini, Q., Badrianto, A., Budiarty, F., Khoirunisa, A., \& Rahardja, U. (2020). Alleviate Fake Diploma Problem In Education Using Block Chain Technology. Journal of Advanced Research in Dynamical and Control Systems, 12(2). https://doi.org/10.5373/JARDCS/V12I2/S20201225.

Alavudeen, S. S., Easwaran, V., Mir, J. I., Shahrani, S. M., Ahmed Mohammed Almodeer Aseeri, A. A., Khan, N. A., \& Asiri, A. A. (2021). The influence of COVID-19 related psychological and demographic variables on the effectiveness of e-learning among health care students in the southern region of Saudi Arabia. Saudi Pharmaceutical Journal. https://doi.org/10.1016/j.jsps.2021.05.009.

Anitha Kumari, T., Hemalatha, C. H., Subhani Ali, M., \& Naresh, R. (2020). Survey on impact and learning's of the online courses on the present era. Procedia Computer Science, 172, 82-91. https://doi.org/10.1016/j.procs.2020.05.167.

Arico, F., Gillespie, H., Lancaster, S., Ward, N., \& Ylonen, A. (2018). Lessons in learning gain: Insights from a pilot project. Higher Education Pedagogies, 3(1), 249-265. https://doi.org/10.1080/23752696.2018.1454845.

Arikunto, S. (2010). Prosedur Penelitian Suatu Pendekatan Praktik. Rineka Cipta.

Arizona, K., Abidin, Z., \& Rumansyah, R. (2020). Pembelajaran Online Berbasis Proyek Salah Satu Solusi Kegiatan Belajar Mengajar Di Tengah Pandemi Covid-19. Jurnal Ilmiah Profesi Pendidikan, 5(1). https://doi.org/10.29303/jipp.v5i1.111.

Baehaqi, M. L. (2020). Strengthening Discipline Character of Students at Muhammadiyah Boarding-School ( MBS ) Muhiba Yogyakarta. Dinamika Ilmu, 20(1), 63-82. https://doi.org/10.21093/di.v20i1.1671.

Bastemur, S., \& Bastemur, E. (2015). Technology Based Counseling: Perspectives of Turkish Counselors. Procedia - Social and Behavioral Sciences, 176(1998), 431-438. https://doi.org/10.1016/j.sbspro.2015.01.493.

Blakely, M. L., McKnight, K. D., Darling, R. A., \& Moody, E. J. (2020). Using an OSCE to assess the potential for assistive technology to enhance communication between student pharmacists and simulated patients who are deaf/hard of hearing. Journal of the American Pharmacists Association, 60(6). https://doi.org/10.1016/j.japh.2020.08.031

Daunic, A. P., Corbett, N. L., Smith, S. W., Algina, J., \& Poling, D. (2021). Efficacy of the social-emotional learning foundations curriculum for kindergarten and first grade students at risk for emotional and behavioral disorders. Journal of School Psychology, 86. https://doi.org/10.1016/j.jsp.2021.03.004.

Eugenia, Raymond, \& Leung, W. N. (2013). Ready for 21st-century Education - Pre-service Music Teachers Embracing ICT to Foster Student-centered Learning. Procedia - Social and Behavioral Sciences, 73. https://doi.org/10.1016/j.sbspro.2013.02.047.

Hazrati-Viari, A., Rad, A. T., \& Torabi, S. S. (2012). The effect of personality traits on academic performance: The mediating role of academic motivation. Procedia - Social and Behavioral Sciences, 32, 367-371. https://doi.org/10.1016/j.sbspro.2012.01.055.

Herman, \& Didin, D. (2020). The influence of work motivation, job satisfaction and work discipline on employee performance in the regional secretariat of Maros district. Jurnal Ad'ministrare, 7(1), 1-8. https://doi.org/10.26858/ja.v7i1.14777.

Hidayati, S. K., Perizade, B., \& Widiyanti, M. (2019). Effect Of Work Discipline And Work Environment To Performance Of Employees. International Journal of Scientific and Research Publications (IJSRP), 9(12). https://doi.org/10.29322/ijsrp.9.12.2019.p9643.

Hofmann, V., \& Müller, C. M. (2021). Language skills and social contact among students with intellectual disabilities in special needs schools. Learning, Culture and Social Interaction, 1. https://doi.org/10.1016/j.lcsi.2021.100534.

Hoi, S. C. H., Sahoo, D., Lu, J., \& Zhao, P. (2021). Online learning: A comprehensive survey. Neurocomputing, 459, 249-289. https://doi.org/10.1016/j.neucom.2021.04.112.

Hu, Y., \& Liu, L. (2020). Becoming industrious female citizens: Work, discipline, and negotiation in Chinese female prison. International Journal of Law, Crime and Justice, 63. https://doi.org/10.1016/j.ijlcj.2020.100420.

Hutauruk, A., \& Sidabutar, R. (2020). Kendala pembelajaran daring selama masa pandemi di kalangan mahasiswa pendidikan matematika: Kajian kualiatatif deskriptif. Journal of Mathematics Education and Applied, 02(01), 45-51. https://doi.org/10.36655/sepren.v2i1.364.

Khan, M. A., Vivek, Nabi, M. K., Khojah, M., \& Tahir, M. (2021). Students' Perception towards E-Learning During Covid-19 Pandemic In India: An Empirical Study. Sustainability, 13(1). https://doi.org/10.3390/su13010057.

Kim, M., Lee, H., \& Kwak, J. (2020). The changing patterns of China's international standardization in ICT under techno-nationalism: A reflection through 5G standardization. International Journal of Information Management, 54. https://doi.org/10.1016/j.ijinfomgt.2020.102145. 
Ko, C. H., Hsiao, S., Liu, G. C., Yen, J. Y., Yang, M. J., \& Yen, C. F. (2010). The characteristics of decision making, potential to take risks, and personality of college students with Internet addiction. Psychiatry Research, 175(1-2), 121-125. https://doi.org/10.1016/j.psychres.2008.10.004.

Kyewski, E., \& Krämer, N. C. (2018). gamify or not to gamify? An experimental field study of the influence of badges on motivation, activity, and performance in an online learning course. Computers \& Education, 118, 25-37. https://doi.org/10.1016/j.compedu.2017.11.006.

Lange, S., Pohl, J., \& Santarius, T. (2020). Digitalization and energy consumption. Does ICT reduce energy demand? Ecological Economics, 176. https://doi.org/10.1016/j.ecolecon.2020.106760.

Lyashenko, M. S., \& Malinina, I. A. (2015). The Use of Learning Management System Projects for Teaching a Foreign Language in the University. Procedia - Social and Behavioral Sciences, 182, 81-88. https://doi.org/10.1016/j.sbspro.2015.04.741.

Marlina, E. (2020). Pengembangan Model Pembelajaran Blended Learning Berbantuan Aplikasi Sevima Edlink. Jurnal Pedagogi, 3(2). https://doi.org/10.35974/jpd.v3i2.2339.

Marzuki, \& Basariah. (2017). The Influence Of Problem-Based Learning And Project Citizen Model In The Civic Education Learning On Student'scritical Thinking Ability And Self Discipline. Cakrawala Pendidikan, 6(3), 382-400. https://doi.org/10.21831/cp.v36i3.14675.

Meriana, T., Angelius Domes, A., -, Y., \& Sihotang, H. (2021). The Impact of the Covid-19 Pandemic on Students Behaviour During Online Learning at Pelangi Kasih Elementary School in Jakarta. Advances in Social Sciences Research Journal, 8(4), 594-604. https://doi.org/10.14738/assrj.84.10112.

Mulyani, M. (2013). An Analysis of English Lesson Plan Academic Year 2012/2013 at the First Semester of MAS Darul Ulum, Banda Aceh. Syiah Kuala University.

Mutohhari, F., Sofyan, H., \& Nurtanto, M. (2021). Technological Competencies: A Study on the Acceptance of Digital Technology on Vocational Teachers in Indonesia. Proceedings of the 1st International Conference on Law, Social Science, Economics, and Education, ICLSSEE 2021, 1-11. https://doi.org/10.4108/eai.6-3-2021.2305971.

Nießen, D., Danner, D., Spengler, M., \& Lechner, C. M. (2020). Big Five Personality Traits Predict Successful Transitions From School to Vocational Education and Training: A Large-Scale Study. Frontiers in Psychology, 11(4), 1-18. https://doi.org/10.3389/fpsyg.2020.01827.

Pratama, F. I. P., Kristiyanto, A., \& Widyastono, H. (2021). Character Values of Third Grade Slow Learner in Character Education at the Inclusive Elementary School. JPI, 10(2), 345-352. https://doi.org/10.23887/jpi-undiksha.v10i2.28838.

Purvis, A. J., Rodger, H. M., \& Beckingham, S. (2020). Experiences and perspectives of social media in learning and teaching in higher education. International Journal of Educational Research Open, 1(November), 100018. https://doi.org/10.1016/j.ijedro.2020.100018.

Purwowidodo, A. (2017). Revitalization of the Role of Recently Madrasah Teacher: Modern Learning Perspective and Utilization of ICT in the Globalization Era. Jurnal Pendidikan Islam, 6(1). https://doi.org/10.14421/jpi.2017.61.169-193.

Putra, R. W. P. (2021). Improving the Students' Motivation in Learning English through Google Meet during the Online Learning. English Learning Innovation, 2(1), 35-42. https://doi.org/10.22219/englie.v2i1.14605.

Putri, A. P., Rahhayu, R. S., Suswandari, M., \& Ningsih, P. A. R. (2021). Strategi Pembelajaran Melalui Daring Dan Luring Selama Pandemi Covid-19 Di Sd Negeri Sugihan 03 Bendosari. Prima Magistra: Jurnal Ilmiah Kependidikan, 2(1), 1-8. https://doi.org/10.37478/jpm.v2i1.728.

Rajagukguk, \& Simanjuntak. (2015). Problem-Based Mathematics Teaching Kitsintegrated With ICT To Improvestudents' Critical Thinking Ability Injunior High Schools In Medan. Cakrawala Pendidikan, 34(3). https://doi.org/10.21831/cp.v3i3.7342.

Sari, R. P., Tusyantari, N. B., \& Suswandari, M. (2021). Dampak Pembelajaran Daring Bagi Siswa Sekolah Dasar Selama Covid-19. Prima Magistra: Jurnal Ilmiah Kependidikan, 2(1), 9-15. https://doi.org/10.37478/jpm.v2i1.732.

Shodiq, I. J., \& Zainiyati, H. S. (2020). Pemanfaatan Media Pembelajaran E-Learning Menggunakan Whastsapp Sebagai Solusi Ditengah Penyebaran Covid-19 Di Mi Nurulhuda Jelu. Al-Insyiroh: Jurnal Studi Keislaman, 6(2), 144-159. https://doi.org/10.35309/alinsyiroh.v6i2.3946.

Suyanto, S. (2018). Competence and discipline on work motivation and the implication on working performance. European Research Studies Journal, 21(1), 570-587. https://doi.org/10.35808/ersj/971.

Thoyyibah, N., Hartono, R., \& Bharati, D. A. L. (2019). The Implementation of Character Education in the English Teaching Learning Using 2013 Curriculum. English Education Journal, 9(2), 254-266. https://doi.org/10.15294/eej.v9i2.30058.

Toropova, A., Myrberg, E., \& Johansson, S. (2021). Teacher job satisfaction: the importance of school working conditions and teacher characteristics. Educational Review, 73(1), 71-97. https://doi.org/10.1080/00131911.2019.1705247. 
Vollmer, C., Randler, C., Horzum, M. B., \& Ayas, T. (2014). Computer game addiction in adolescents and its relationship to chronotype and personality. SAGE Open, 4(1). https://doi.org/10.1177/2158244013518054.

Wagiran, Pardjono, Suyanto, W., Sofyan, H., Soenarto, S., \& Yudantoko, A. (2019). Competencies of Future Vocational Teachers: Perspective of in-Service Teachers and Educational Experts. Cakrawala Pendidikan, 38(2), 388-400. https://doi.org/10.21831/cp.v38i2.25393.

Wan Hassan, W. A. ., Ariffin, A., Ahmad, F., Sharber, S. N. ., Azizi, N., \& Zulkiflee, S. . (2020). COVID-19 Pandemic : Langkawi Vocational College Student Challenge in Using Google Classroom for Teaching and Learning ( $\mathrm{T} \& \mathrm{~L}$ ). International Journal of Advanced Trends in Computer Science and Engineering, 9(3), 3299-3307. https://doi.org/10.30534/ijatcse/2020/127932020.

Wegmann, K. M., \& Smith, B. (2019). Examining racial/ethnic disparities in school discipline in the context of student-reported behavior infractions. Children and Youth Services Review, 103. https://doi.org/10.1016/j.childyouth.2019.05.027.

Wibowo, A., \& Rahmayanti, I. (2020). Penggunan Sevima Edlink Sebagai Media Pembelajaran Online untuk Mengajar dan Belajar Bahasa Indonesia. Imajeri: Jurnal Pendidikan Bahasa Dan Sastra Indonesia, 2(2), 163-174. https://doi.org/10.22236/imajeri.v2i2.5094.

Wijaya, H., Tari, E., Sumule, L., Weismann, I. T. J., \& Supartini, T. (2021). Online Learning Evaluation in Higher Education: Study Survey Method. Journal of Education Technology, 5(3), 401-408. https://doi.org/10.23887/jet.v5i3.35466.

Windhiyana, E. (2020). Dampak Covid-19 Terhadap Kegiatan Pembelajaran Online Di Perguruan Tinggi Kristen Di Indonesia. Perspektif Ilmu Pendidikan, 34(1), 1-8. https://doi.org/10.21009/pip.341.1.

$\mathrm{Yu}, \mathrm{Z}$. (2021). The effects of gender, educational level, and personality on online learning outcomes during the COVID-19 pandemic. International Journal of Educational Technology in Higher Education, 18(1), 117. https://doi.org/10.1186/s41239-021-00252-3.

Yuliandi, \& Tahir, R. (2019). Work discipline, competence, empowerment, job satisfaction, and employee performance. International Journal of Recent Technology and Engineering, 8(3), 7209-7215. https://doi.org/10.35940/ijrte.C6221.098319.

Yuliantika, S. (2017). Analisis Faktor-Faktor Yang Mempengaruhi Disiplin Belajar Siswa Kelas X, Xi, Dan Xii Di Sma Bhakti Yasa Singaraja Tahun Pelajaran 2016/2017. Jurnal Pendidikan Ekonomi Undiksha, 9(1), 35. https://doi.org/10.23887/jjpe.v9i1.19987. 